\title{
Luweng as a Traditional Cultural Heritage
}

\author{
Koniherawati $^{1}$ \\ ${ }^{1}$ Product Design Department, Faculty of Architecture and Design \\ in Duta Wacana Christian University Yogyakarta, Indonesia \\ Corresponding Author’s Email: gentong_koni@yahoo.com
}

\begin{abstract}
The culinary culture that is constantly developing in various countries and regions cannot be separated from the existence of a cooking culture that is unique. In Indonesian traditional cooking culture, there is a cooking tool called luweng. Luweng made from clay is a specifically of kitchenware that can be considered of the most traditional types of pottery, it does not need the process of firing. The existence of pottery was brought to life by human civilization, where during the times ancient humans were not nomadic, to live farming, then began to create necessary equipment. Cooking, eating and drinking utensils were made using natural materials found in surroundings. Clay being the main source of earthenware exemplifies the simplicity and sensitivity humans show to nature for survival. Luweng is a traditional cooking stove is very interesting and fascinating especially to show the local genius of ancient humans. Luweng is used by rural communities to cook using wood or dry twigs as fuel. Its simple shape consists of rectangles with several holes at the top that are made according to the heat generated. Special ancestors skills passed down from generation to generation are transfer of knowledge in the traditional education culture. Furthermore, this research will find the unique functions of Luweng that are still used by rural communities at the countryside in Indonesia, are artifacts in traditional culture that still survive in this modern technology era. This paradox although is very interesting to have been criticized, and proven to have inspired writers when ideating installation art concepts. Through this research and artwork are expected to become a track record and a new knowledge for young to learn about history; particularly on cooking tools and traditional culture.
\end{abstract}

Keywords: Luweng, cooking tools, cooking culture, traditional technology and culture

\section{INTRODUCTION \\ Background}

The kitchen in the layout of the house especially in Java is often placed in the back or side of the house, even separated from the main room (living room) because it is considered a dirty room. Likewise in the ancient Javanese domestic life, a woman (wife) is often referred to as konco wingking (rear friend) husband, because the main task of a housewife is cooking in the kitchen located behind the 
house and caring for the children. In fact, the existence of the kitchen is the heart of the household, because that is where the necessities of food and drink are made or prepared for the whole family. There is even the term sing penting dapur ngebul (meaning, the important thing is that either the kitchen stays smoky or there are activities), this implies that the household economy is good if the family is supplied with food. This exemplifies why the existence of the kitchen is very important in a household. The most highlighted kitchen furniture is a cooking stove, which must be constantly left ignited, representing the need for food - drink for all family members is fulfilled.

Design of the cooking stove from time to time apparently there is a change. Initially, early humans only knew to only cook food (hunting animals) using wood or dry branches. With development, they learnt how to cook by using a container (pot) of clay that serves to boil meat or food ingredients, then humans use stones for cooking pot holder. After humans began to live

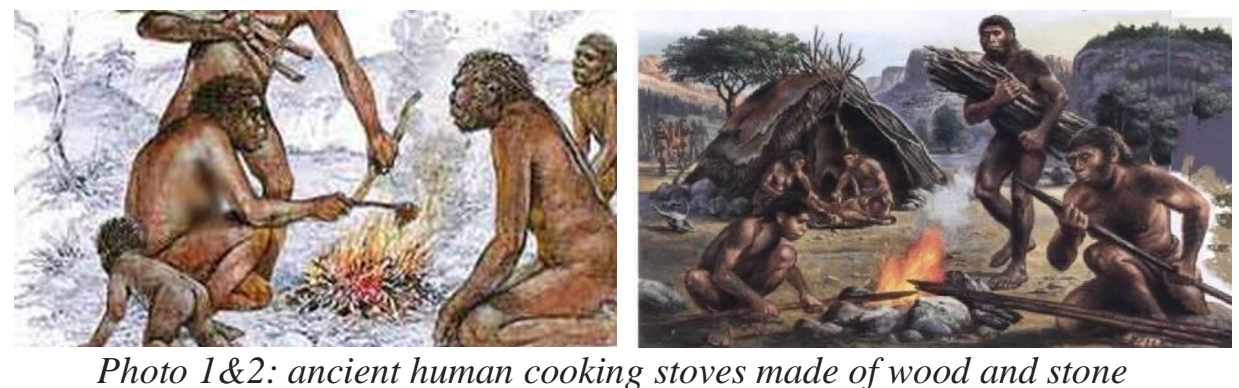

permanently and grow crops, then technology began to make cooking stoves stronger or more permanent. Humans began to use technology to turn natural resources into simple tools. Technology is a whole means to provide goods needed for the survival and comfort of human life. Prehistoric discoveries about the ability of humans to control fire have increased the availability of food sources. Through technology in making cooking tools that are more permanent by using clay to make it stronger and durable. The development in the form of cooking tools is evidence to the development of human civilization. It is interesting to observe and research based on this topic in order to understand a culture, especially when it comes to cooking. The cooking stoves to be explored in this research are traditional stoves which are commonly called luweng, and are still widely used by rural communities throughout Indonesia, especially in Central Java, this allows luweng craftsmen to continue producing it.

Luweng is a traditional cooking stove with a simple shape, that is, a long rectangle has several holes on it that function differently in the cooking process. Thus the activity of cooking using luweng, can cook several types of food or vegetables, and boil water to keep warm at the same time. While the fuel to light a fire in luweng is through the use of wood or dry branches. Traditional cooking stoves that look simple with a few holes above luweng has different according 

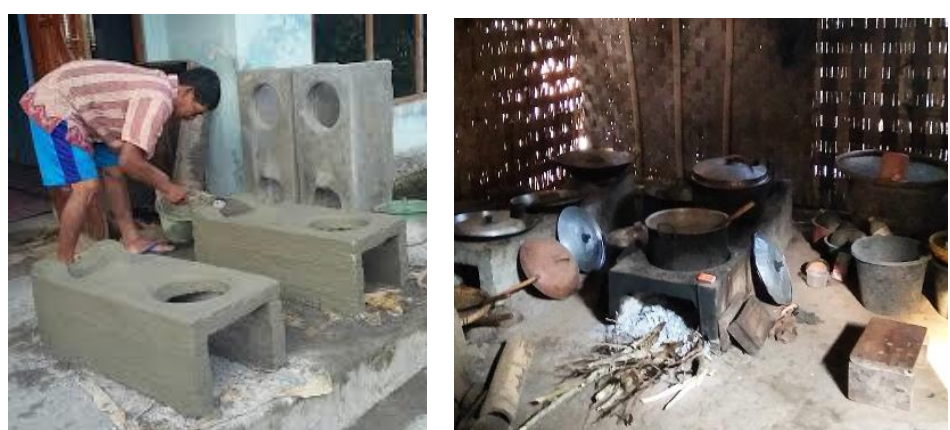

Photo 3\&4: Luweng, a traditional cooking stove with several cooking holes

to the temperature of the heat produced from the fire.

When the Indonesian government (then President SBY) in 2001 issued a policy of changing fuel oil to gas, where the government distributed gas stoves (modern cooking) and their equipment such as hoses, regulators and gas cylinders to the poor throughout Indonesia. One of the goals proclaimed by the government is to improve and equalize the welfare of the low-income Indonesians. Many problems arose as a result of the use of modern cooking tools, the biggest occurred when the stove or gas cylinder exploded, and consequently took many lives. At that time, the government may not have considered the cooking culture of the poor in rural areas who were accustomed to using traditional stoves

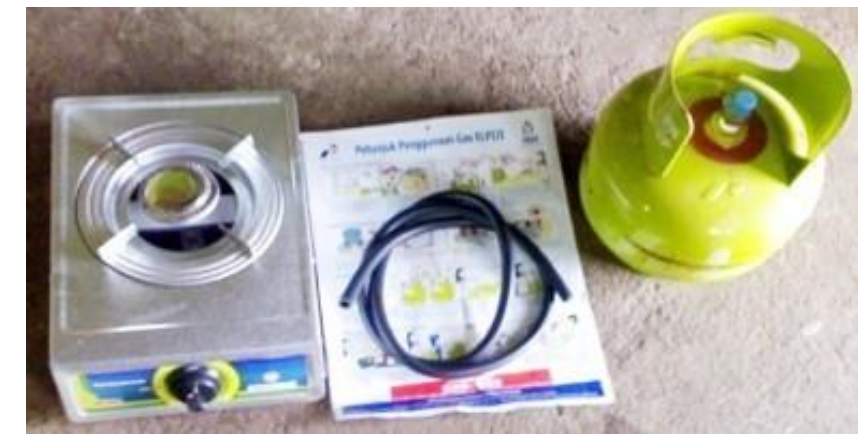

Photo 5: Gas stove and accessories (hoses, regulators and gas cylinders) divided by the government to the poor -2001

and being forced to suddenly change to the use of a gas stove. Luweng trait that use wood fuel is very different from the modern cooking fueled by gas. There in lies the problem that occurs, where there is a forced cultural jump. The two cooking utensils are very different in terms of techniques and treatments in the way that they are used and their properties, including the nature of the material used for the furnace, the fuel, the occurrence of fire / heat temperature, the placement space and the working time of the process. This is the reason why I am interested in researching about luweng as a traditional cultural heritage of ancestors that shows local wisdom. 


\section{Problem Formulation}

1. Understand traditional luweng technology and how it works according to function.

2. What is the relationship with work activities of housewives?

3. What is the relevance in technological change in cooking culture?

\section{Research Objectives and Benefits}

\section{Purpose}

To understand the existence of luweng as a traditional cultural heritage that suit the needs of people in the countryside.

\section{The benefits}

This research will demonstrate why the local wisdom that has been owned by the ancestors cannot be ignored by changing the culture of cooking using modern tools in a sudden matter,

\section{LITERATURE REVIEW}

\section{Understanding Kitchen}

Kitchens in Javanese society, often called pawon, are part of the home or household. Pawon is defined as a place of ash or $a w u$ (pa-awu-an). Thus the consideration of it being a dirty place that is generally located behind the house. Typically the pawon (kitchen) building is made after the house construction is completed, and as an additional building the construction of the kitchen building is made very simple, no complicated requirements are needed unlike the construction of the main house which requires primbon (time calculation) as well as offerings. According to Koentjaraningrat, there is a belief among Javanese people that the kitchen is the weakest part of the house, because the kitchen is a place where women are considered weak creatures (liyu). While the word liyu according to the JavaneseIndonesian Bausastra, means to be tired, working in the kitchen is indeed tiring. (Sumintarsih, 1991: 16-18) Thus the pawon has an integral function and is the territory of Javanese women. There, Javanese women were free to create and control their family's appetite. A family's life starts from the what takes place in the kitchen, carried out by women / housewives in preparing and cooking in the kitchen and its relation to other domestic tasks. In Javanese society, known as Luweng, the term for a traditional stove, a place for cooking is formed from clay, rectangular in shape with a few holes, the fuel used is firewood / tree branches. Luweng as a place for cooking is part of the kitchen (pawon).

\section{Technology}

In a simple understanding of technology is a way to convert natural resources into simple tools. Technology here is a whole means to provide goods needed for the survival and comfort of human life. Meanwhile, according to the sociology dictionary, technology includes all forms of productive techniques, including the work of hands, and technology is not synonymous with machinery, as it is commonly associated. In the sociology of work and the world of work, this 
term also includes the physical organization of production - this is the means of production hardware being organized in the workplace - so that it includes the division of labor built inside and required for efficient operation through production techniques. Production techniques and production organizations are social products, a result of human decision making. Thus technology is considered as a result of social processes (Abercrombie, et al. 2010).

\section{METHODOLOGY}

The method that will be used in this research is ethnography approach through direct observation, interviews and literature studies.

\section{Research Scope}

Specific research on traditional luweng and observing the cooking behavior or habits of mothers in rural areas and domestic activities.

\section{Data Analysis Methods}

The data that has been obtained are analyzed using an interpretive approach, which describes everything that is behind the data. The research process is carried out continuously, through data collection, data processing and analysis, before drawing conclusions. Meanwhile, existing theories are used as tools to help analyze data.

\section{ANALYSIS}

\section{Culture of Cooking in the Villages}

As stated by Juhani Salovaraa, a product designer in his research for traditional farming families in Finland, it was mentioned that the kitchen stove is the heart of the house. The kitchen is the core of the whole house, and the stove is situated in the middle of the house, therefore making it the center of the house. (Vihma, et al. 1990: 369-370) The first work done in the kitchen is to light a fire (daden geni) in a stove / luweng, so that the kitchen is also believed to be a place of life in the family, because the kitchen is a place to cook / provide food all family. So if the kitchen fire does not ignite, there is no life in the family. (Sumintarsih et al, 1991: 145-148) Activities carried out by housewives in the kitchen (pawon) are from lighting fires, cooking vegetables and boiling drinking water while completing other household chores such as: sweeping the yard, cleaning the house, washing clothes and caring for their children until the cooked food is ready to be served to their family. Juhani Salovaraa further mentioned that when observing the kitchen now (modern), the kitchen is only a small part of the house and is occasionally a fairly small space. Most people nowadays eat in their living rooms, and breakfast is made in a hurry in the kitchen (Vihma, et al. 1990: 371). Modernization creates convenience or practicality in function, space and time, but at the same time shifts family social relations. 


\section{Technology in Cooking Culture}

It was mentioned earlier, that activities in the kitchen certainly cannot be separated from cooking tools as a vital (primary) need. In Javanese society, Luweng as a traditional stove for cooking from clay, rectangular in general has two to four holes. The names of the luweng parts are: cangkem (mouth luweng) for the place to put firewood, then a hollow luweng for a place to put cooking utensils kuali (a tradisional pan made from clay), wajan, kendhil. Where as the precarious shards placed on top to cover the holes in the fire cavity coming out through the upper hole are called lawes. And blengker (base) placed on the face of the flexible tube is used as a fuel base so that the fire in the hollow, for air circulation. Each hole has a different cooking function. The hole close to the cangkem has high heat which functions to fry or sauté and the middle hole functions to cook vegetables soup so that the soup does not evaporate/deplete, and

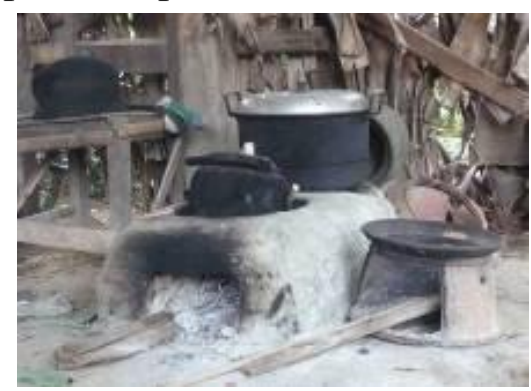

Photo 6: Luweng

the hole farthest away from the smallest sized flexible cangkem to heat drinking water so that it continues to warm without water evaporating.

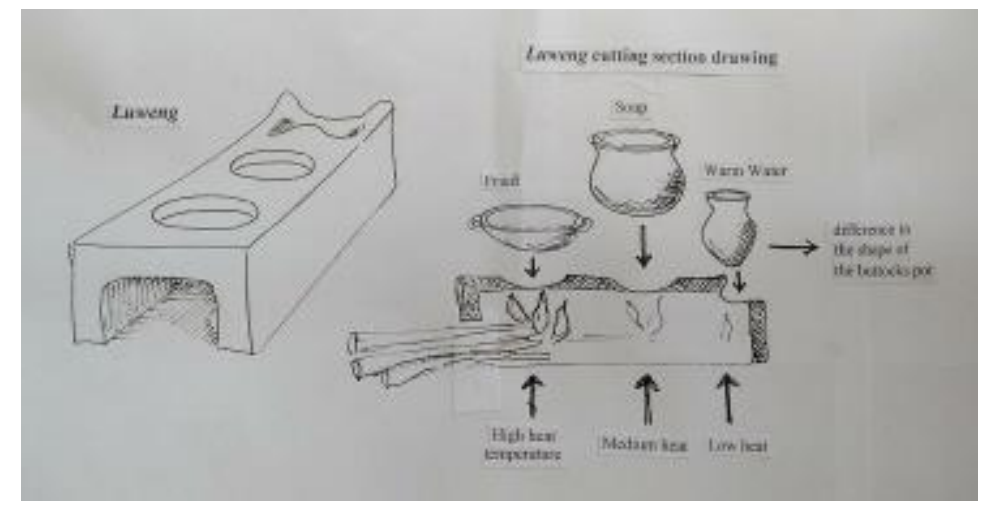

Photo 7: Drawing of "luweng" (left) and cutting Section (right)

The kitchen is part of the house that can not be separated from its inhabitants. Some cooking activities can be carried out at once together, such as: cooking rice, boiling water. While waiting for cooked rice and boiling water, a mother can do other work such as washing vegetables, or sweeping and cleaning the yard and house. The function of the kitchen in large or special activities becomes a place to work together and socialize with neighbors and the community. 
In household kitchens, luweng is generally used when there are special needs, for example: marriage ceremonies, salvation and so on. This is due to the fact that an event usually requires a large amount of cooking to be done. As a result, the atmosphere of mutual assistance was built during the celebration (Sumintarsih, 1990: 145-148).

The technology developed in human civilization is the result of learning and its ability to create a system that eventually becomes one of the elements of universal culture and civilization. In Teknologi dan Manusia Industi (Technology and Human Industry), Victor C. Ferkiss said that technology and scientific knowledge exist to eliminate existing poverty, prevent environmental pollution, and make the world a better place for human life. Meanwhile Mochtar Lubis stated that the greatest danger is if technology is placed on the values of well-being, and in reality, the skill of finding tools to shape human culture. Thus homo faber which makes him homo sapiens (Mangunwijaya, 1985: ix). Just as a change in cooking utensils from traditional forms and techniques called luweng to modern forms and techniques called gas stoves (kompor gas) have very different usabilities. Differences include the type and nature of the materials used in making the cooking tools, the type and character (trait) of the fuel (from firewood to gas); cooking space and time; cooking activities according to local culture (Indonesia); form and function of cooking utensils. As explained above, the several holes on luweng for each has a different function in cooking, whereas the gas stove only has a single hole (single plate). Even the ability or economic strength of the family can be seen from the situation and condition of the cooking place called the kitchen.

In its history, the Industrial Revolution in Europe has created developments in industrial capitalism which have until now penetrated national borders throughout the world. Technological advances create mass production techniques. This condition does not stop at the discovery of new technology, but also how the market is expanded and formed. This technological change towards machinery is driving the rise of manufacturing production, which in turn affects the social, political, economic and cultural life (Susetiawan, 2009).

\section{Technological Progress and the Destruction of Traditional Values}

The fact that many accidents occurred after the replacement of traditional cooking stoves with modern stoves (gas stoves), has led to many debates including technological advances considered as an objective of capitalism. As pointed out by anti-technologists such as Jacques Ellul in The Technologycal Order; technology does not give us neutral tools to enhance our comfort and broaden our horizons. Technology tends to destroy traditional values by imposing a methodology that looks at all human problems in a quantitative way (Wright, Ed. 1997: 154-155). Furthermore technological advances (modern technology) are considered to cause oppression of women who are seen as technology blinds. We see the phenomenon at this time there are many men who become chefs. The Marxist view says that domestic work contributes to capitalism, which is known as the 'domestic labor debate', where women do most of the domestic work, such as cooking food, washing clothes and caring for children, while men work outside the house. So there 
is a subordination of women with capitalism. The production process of modern society involves the relations of capitalists and men (patriarchal). This opinion is based on two aspects in the economic situation of women. First, the position of women in the labor market is different from that of men: women tend to be paid less, are concentrated in more limited types of work, and are less likely to be employed than men, and if so, are often employed as part-time. In addition to the issue regarding payment and recognition, women are generally most involved in unpaid domestic work at home (Jackson, Ed. 2009: 26-27).

By substituting luweng for gas stoves, rural women become very dependent on men, with regards to replacing gas cylinders. These conditions reinforce the opinion, that technology is the field of men (masculin), which is a tool that is only controlled by men, while women do monotonous tasks and require patience or perseverance, such as household chores: cooking, caring for children and cleaning. The condition of masculine technology by Pierre Bordieu referred to as symbolic violence that often causes injustice to the power model. In this case injustice in the division of labor, called symbolic because the effects commonly seen in physical violence are not visible. There were no visible injuries, no traumatic consequences, no fear or anxiety, even the victims did not feel that they had been dominated or manipulated. Bourdieu further said, symbolic violence took place through the ignorance, confession or feelings of the victims. The division of labor in the form of household tasks for women and public activities for men is the result of historical development, so it can be changed, not natural order. The division of labor between women's and men's duties is known as one of the concepts of gender. The concept of gender is a trait inherent in men and women socially and culturally constructed. This is called Bourdieu, ideological values that can be formed because of ownership or the interests of capital. (Haryatmoko, 2010: 128131).

As technology changes, it also changes the shape of a traditional cooking appliance luweng into an oil stove. Changes in technology in cooking tools forced by the government have shifted traditional culture into modern culture and created different usage procedures. Talking about the shape and how to use the cooking tool is not free from design problems.

Design is something that arises when art meets industry, when people start making decisions about what products should be made in bulk. (Walker, 2010:29)

Talking about design is inseparable from technological problems, design is a production process that not only concerns the problem of technological progress, but also involves the interdisciplinary social sciences, including culture, sociology and anthropology. A design is created to meet the needs of the function, but as technology advances, the design has evolved not just a function need, but as other needs are created, the 'image'. A new technology is designed so that it can be a symbol of the user's social status. Thus changes in culture. This cannot be separated from the interests of capitalism. Another thing, changing the luweng cookware 
model to the shape of a kerosene stove, then to a gas stove, has changed the technique of its functionality and usage, where the gas stove is easier to ignite. This has changed the meaning in the kitchen, that modern kitchens are no longer synonymous with women. In this modern age, many men work as chefs, and even the practicality of how to use the stove has changed the activities of 'mutual cooperation' and social kitchen activities become fast or even instant and individual. The location of the kitchen has been moved to the front, close to the dining room or family room. In terms of layout and interior, a modern kitchen is placed in front so that the mother (parent) who is cooking is able to watch her children play in the front yard of the house. Land prices are increasingly expensive so that many small type houses that do not have a playing ground for children, front yards or public roads double function as one. An independent and individual lifestyle allow guests to make their own drinks and wash their glasses, so that the kitchen is located in the front near the living room, shifting the purpose of the kitchen as a gathering place. The kitchen becomes a private place. Louis Lucker, a Dutchman who started a research project in Finland, said:

"... the kitchen was the heart of the home; We talked about the kitchen stove, but it seems to me that the kitchen is the whole house. The stove is in the middle of the house, as the center of the house. "

"... the kitchen is now only a small part of the house, even a very small space and some people eat in their family rooms. Only breakfast is rushed in the kitchen "(Vihma, et al. 1990: 370-371)

Traditional luweng used twig or wood fuel is shown to cause pollution, through the release of black smoke (angus). Therefore the kitchen wall is usually made of woven bamboo so that the smoke can come out through the cracks of the matting and the roof. While replacing modern cooking utensils requires a fairly clean room such as a brick or cement wall to be safe from sparks. It also needs ventilation for good air circulation to avoid gas leaks that can cause explosions.

\section{CONCLUSION}

The study of the evolution and introduction of technology has documented the way in which the technology was deliberately designed according to human needs. Habits that have been carried out for years by humans will shape culture, in this case the technology of cooking tools (furnaces) creates a culture of cooking. The existence of Luweng as a traditional cooking tool was created according to the needs of rural communities. Luweng as a cultural heritage (cooking) shows how the persistence of work and the patience of women in rural areas who are poorly educated and loyal to their families become a value or conception. Luweng as a traditional cultural heritage cannot necessarily be replaced with a modern tool (gas stove) as practiced by the government. New technology should be created by the gradual process of modification, refinement and new combinations of existing technologies. Changes in technology should be considered more closely so as not to create a cultural lag that may cause problems in society. 
Thus the reason why the socio-cultural, economic and user knowledge levels need to be considered in creating or introducing new technologies.

\section{BIODATA}

Koniherawati is a assistant professor of Product Design Department, Faculty of Architecture and Design in Duta Wacana Christian University, Yogyakarta. Now still stydy in Doctoral Program at Sanata Dharma University, Yogyakarta. And as an artist. She actives participant in art exhibitions (ceramics, painting and installation art). Her main research on traditional poterry (ceramics), crafts and culture studies.

\section{REFERENCES}

Cassierer, Ernst. 1987. "Manusia dan Kebudayaan: Sebuah Esei Tentang Manusia”. Jakarta: Gramedia.

Creswell, John W. 2010. "Research Design - Pendekatan Kualitatif, Kuantitatif, dan Mixed". Yogyakarta: Pustaka Pelajar.

Sarosa, Samiaji, S.E., M.Info.Sys., Ph.d. 2017. "Penelitian Kualitatif - DasarDasar”. Jakarta: Indeks.

Abercrombie, Nicholas, at al. 2010. Kamus Sosiologi. Yogyakarta: Pustaka Pelajar.

Barker, Chris. 2009. Cultural Studies: Teori \& Praktik. Terj. Nurhadi.Yogyakarta: Jalasutra.

Baswir, Revrisond. 2009. Bahaya Neoliberalisme. Yogyakarta: Pustaka pelajar.

Bourdieu, Pierre. 2010. Dominasi Maskulin. Terj. Stephanus Aswar Heswinarko. Yogyakarta: Jalasutra.

Budiman, Kris. 1997. Rumah (Ber)Tangga - Irwan Abdullah, (Ed). Dari Domestik ke Publik: Jalan Panjang Pencarian Identitas Perempuan-Sangkan Paran Gender. Yogyakarta: Pustaka Pelajar.

Connell, R.W. 1987. Gender and Power. Society and Power Society. The Person and Sexual Politics. UK: Polity Press.

Denzin, Norman K. and Yvonna S. Lincoln. 2009. Handbook of Qualitative Reasearch. Terj. Yogyakarta: Pustaka Pelajar.

Group, Gender Working, United Nation Commission on Science and Technology for Development. 1995. Missing Links: Gender Equity in Science and Technology for Development. Canada: international Development Research Centre.

Habermas. 1990. Ilmu \& Teknologi sebagai Ideologi. Jakarta: LP 3ES.

Haryatmoko. 2010. Dominasi Penuh Muslihat: Akar Kekerasan dan Dominasi. Jakarta: Gramedia.

Jackson, Stevi dan Jackie Jones, Ed. 2009. Pengantar Teori-Teori Feminis Kontemporer. Yogyakarta: Jalasutra.

Jenkins, Richard. 2004. Membaca Pikiran Bourdieu. Yogyakarta: Kreasi Wacana. 
Mangunwijaya. 1985. Teknologi dan Dampak Kebudayaan. Vol.II, Jakarta: Yayasan Obor.

Ritzer, George and Barry Smart. 2011. Handbook Teori Sosial. Bandung: Nusamedia.

Soegondho, Santoso. 1995. "Tradisi Gerabah di Indonesia - Dari Masa Prasejarah Hingga Masa Kini”. Jakarta: P.T. Dian Rakyat.

Spradley, James P. 2007. Metode Ethnografi. Yogyakarta: Tiara Wacana.

Stokes, Jane. 2007.How To Do Media and Cultural Studies: Panduan untuk Melaksanakan Penelitian dalam Kajian Media dan Budaya. Yogyakarta: Bentang.

Sumintarsih, dkk. 1990. Dapur dan Alat-alat Memasak Tradisional DIY. Yogyakarta: Departemen Pendidikan dan Kebudayaan.

Susetiawan. 2009. Ketidakberdayaan Para Pihak Melawan Konstruksi Neoliberalisme, Yogyakarta: PSPK-UGM.

Terry, Jeniffer and Melodie Calvert, Ed. 1997. Gender and Technology in Everyday Life. London: Routledge.

Vihma, Susann \& Seppo Vakeva. 1990. Semantic Vission in Design. Yogyakarta: Jalasutra.

Walker, John A. 2010. Desain, Sejarah, Budaya: Sebuah pengantar komprehensi. Yogyakarta: Jala Sutera.

Wright, Barbara Drygulski „Ed. 1997. Kiprah wanita dalam Teknologi-Triplett, Timm. Kaum Wanita Kepulauan Hebrida: Pandangan Seorang Fisuf Tentang Teknologi dan Perubahan Budaya. Bandung: Remaja Rosdakarya. , Carol J. Haddad. Teknologi, Industrialisasi, dan Status Ekonomi Wanita,

\section{Internet:}

google.com./kasus\%20No.3\%20Konversi\%20Minyak520Gas.pdf., tulisan Wilda Asmarini-Okezone, "Pertamina Targetkan Konversi Gas Hemat Rp 9,6 T". Jumat 21 Mei 2010, pk 18:07 wib. , tulisan Kumoro, staff.ugm. 2 Desember 2011, 3.37pm.

\section{Journal:}

Jurnal Perempuan, Untuk Pencerahan dan Kesetaraan: Ilmu Pengetahuan dan Perempuan, No. 48, 2006. Jakarta: Yayasan Jurnal Perempuan. 